\title{
Pengaruh Kandungan Energi dalam Pakan Konsentrat terhadap Kinerja Domba Persilangan (Garut x st Croix x Multon Charolais) Induk
}

\section{(Effect of Energy Level in Concentrate Feed on the Performance of Cross Bred Ewes (Garut x St Croix x Multon Charolais) Ewes}

\author{
Yulistiani $\mathrm{D}^{1}$, Puastuti $\mathrm{W}^{1}$, Subandriyo ${ }^{1}$, Sudrajat $\mathrm{D}^{2}$ \\ ${ }^{1}$ Balai Penelitian Ternak, P.O. Box 221 Bogor \\ ${ }^{2}$ Universitas Djuanda, Ciawi Bogor \\ dyulistiani@yahoo.com
}

\begin{abstract}
Study was conducetd to evaluate the effect of feeding increasing level of energy content of concentrate supplementation on the performance of lactating ewes of cross bred sheep (Garut x St Croix x Multon Charolais). The study used 33 heads ewes, placed into 9 grouped pen based on their body weight and fed on one of three concentrate treatments. The three concentrate diet treatments were formulated in iso protein contained 3 levels energy content. The diet treatments were TDN 68\% (R1); TDN 73\% (R2) and TDN 78\% (R3) or equal to Metabolizable energy (ME) of $2212 \mathrm{kcal} / \mathrm{kg} ; 2375 \mathrm{kcal} / \mathrm{kg}$ and $2535 \mathrm{kcal} / \mathrm{kg}$ respectively for R1, R2 and R3. The concentrate were fed at $2 \%$ body weight. Parameter recorded were: feed consumption, body weight of ewes just after lambing, lamb birth weight, ewes weight at weaning and lambs weaning weight. Study was conducted in a randomized completely block design. Threre was no significant effect of increasing energy levels on DM and CP intake. Energy intake increased with increasing energy levels of concentrate. Lambs birth weight, weaning weight and ADG during preweaning per-head or per-ewes was not significantly different $(\mathrm{P}>0.05)$ among treatments with the average of $2.46 \mathrm{~kg} / \mathrm{head} ; 12 \mathrm{~kg} / \mathrm{head} ; 94.3$ $\mathrm{g} / \mathrm{head} /$ day or $3.55 \mathrm{~kg} / \mathrm{ewes}, 15.6 \mathrm{~kg} / \mathrm{ewes}$, and $121 \mathrm{~g} / \mathrm{head} / \mathrm{ewes}$, respectively. Ewes body weight at lambing, body weight at weaning and ADG during lactation was not significantly different $(\mathrm{P}>0.05)$ between treatments with the average of $37.12 \mathrm{~kg} ; 35.1 \mathrm{~kg}$ and -22.76 $\mathrm{g} / \mathrm{h}$ ead/day, respectively. Lamb mortality at preweaning period was $15 \%$. From this study, it can be concluded that supplementation at $2 \%$ body weight of concentrate containing $16 \% \mathrm{CP}$ and $2 \mathrm{Mcal} / \mathrm{kg}$ metabolizable energy to fresh chopped elephant grass basal diet ad libitum was able to meet energy and protein requirement of lactating ewes. Further research needs to be done on concentrate supplementation starting from late pregnancy to reduce weight loss of ewes during lactation.
\end{abstract}

Key words: Energy, concentrate, ewes, lactation, lamb

\begin{abstract}
ABSTRAK
Penelitian dilakukan untuk mengevaluasi pengaruh suplementasi pakan konsentrat pada berbagai level kandungan energi terhadap tampilan domba persilangan Komposit Garut (Garut x St Croix x Multon Charolais) induk fase laktasi. Penelitian menggunakan 33 ekor domba induk, yang dikelompokkan menjadi 3 kelompok berdasarkan bobot badan. Tiap kelompok mendapatkan salah satu dari pakan perlakuan, domba ditempatkan pada 9 kandang kelompok. Setiap perlakukan terdapat 3 ulangan kelompok. Perlakuan pakan konsentrat tersebut adalah TDN 68\% (R1); TDN 73\% (R2) and TDN 78\% (R3) atau sama dengan energi metabolis (ME) of $2212 \mathrm{kkal} / \mathrm{kg} ; 2375 \mathrm{kkal} / \mathrm{kg}$ and $2535 \mathrm{kkal} / \mathrm{kg}$ secara berurutan untuk R1,
\end{abstract}


R2 dan R3dan diberikan sebanyak $2 \%$ bobot badan. Parameter yang dicatat adalah konsumsi pakan, bobot badan induk sesaat setelah beranak, bobot lahir anak, bobot induk saat menyapih dan bobot sapih anak. Penelitian dilakukan menggunakan rancangan acak kelompok. Hasil penelitian menunjukkan tidak ada pengaruh nyata perbedaan tingkat energi pakan terhadap konsumsi bahan kering dan protein kasar. Konsumsi energi meningkat dengan meningkatnya kandungan energi pakan konsentrat. Bobot lahir anak, bobot anak saat sapih dan pertambahan bobot badan harian anak prasapih tidak berbeda nyata $(\mathrm{P}>0,05)$ antar perlakuan dengan rataan 2,46 kg/ekor; $12 \mathrm{~kg} / \mathrm{ekor}$ 94,3 g/ekor/hari atau 3,55 kg/induk, 15,6 kg/induk, dan 121 g/ekor/induk secara berurutan. Demikian pula tidak ada pengaruh nyata $(\mathrm{P}>0,05)$ perlakuan terhadap bobot induk saat beranak dan bobot induk saat menyapih anak serta PBBH fase laktasi dengan rataan $37,12 \mathrm{~kg} ; 35,1 \mathrm{~kg}$ dan $-22.76 \mathrm{~g} / \mathrm{ekor} / \mathrm{hari}$ secara berurutan. Kematian anak pra-sapih $15 \%$ pada perlakuan R1 dan R2. Dari hasil penelitian dapat disimpulkan bahwa suplementasi konsentrat sebanyak $2 \%$ bobot badan induk dengan kandungan protein $16 \%$ dan energi metabolis $2 \mathrm{Mcal} / \mathrm{kg}$ pada pakan dasar rumput gajah yang diberikan secara ad libitum mampu mencukupi kebutuhan protein dan energi domba komposit garut fase laktasi. Perlu dilakukan penelitian lebih lanjut untuk suplementasi konsentrat dilakukan mulai dari bunting tua untuk mengurangi atau menjaga induk dari kehilangan bobot badan saat laktasi dan menurunkan angka kematian anak prasapih.

Kata kunci: Energi, konsentrat, induk, laktasi, anak domba

\section{PENDAHULUAN}

Ternak domba di Indonesia pada umumnya mempunyai tingkat prolifikasi yang tinggi (Bradford 1993), namun pada umumnya mempunyai ukuran tubuh yang kecil. Banyak usaha dilakukan untuk meningkatkan bobot badan antara lain dengan dengan pemberian pakan berkualitas tinggi, namun hal ini tidak akan tercapai apabila tidak didukung oleh potensi genetiknya. Salah satu upaya meningkatkan prodktivitas domba lokal melalui perbaikan mutu genetik dengan cara perkawinan ternak dari bangsa yang berbeda (cross breeding) yang disertai dengan kegiatan seleksi. Domba komposit Garut merupakan domba hasil persilangan domba lokal Garut dengan domba eksotik Moulton Charolais dan domba St Croix yang dilakukan di Balitnak. Domba Komposit Garut mempunyai komposisi genotipa terdiri dari 25\% Moulton Charolais, 25\% domba St Croix dan 50\% domba lokal Garut. Domba komposit mempunyai sifat dapat beranak sepanjang tahun dengan jumlah anak 2 ekor seperti yang ditampilkan oleh domba prolifik Garut, mempunyai kerangka tubuh yang besar sehingga memberi peluang fetus untuk tumbuh optimal, mempunyai daya tahan terhadap cuaca panas dan lembab seperti yang ditampilkan domba hairsheep St Croix, serta mempunyai produksi susu yang cukup untuk merawat anak 2 ekor serta komposisi perdagingan yang baik seperti ditampilkan oleh domba Moulton Charolais (Subandriyo et al. 2009).

Produktivitas ternak pada dasarnya selain dipengaruhi oleh faktor genetik dipengaruhi juga oleh faktor lingkungan. Kemampuan ternak untuk berproduksi sesuai dengan potensi genetiknya dipengaruhi oleh beberapa faktor lingkungan yang salah satunya adalah faktor kebutuhan nutrisi. Oleh karena itu untuk dapat berproduksi dengan baik maka kebutuhan nutrisinya harus terpenuhi. Kebutuhan nutrisi tertinggi pada induk terjadi pada pada masa akhir kebuntingan dan waktu awal setelah kelahiran. NRC (2007) menyarankan meningkatkan pemberian energi pakan $60 \%$ lebih tinggi dari periode awal kebuntingan. Tingginya kebutuhan nutrisi ini pada akhir kebuntingan ini disebabkan karena 70-85\% pertumbuhan foetus terjadi pada 6-8 minggu akhir kebuntingan (Robinson 1986) menyebabkan peningkatan kebutuhan nutrisi induk. Meningkatnya ukuran dan 
berat foetus yang diikuti dengan bertambahnya masa placenta membran foetus dan cairan uterine (Russel 1979), menyebabkan kebutuhan nutrien (energi dan protein) meningkat. Oleh karena itu pada masa akhir kebuntingan induk harus mendapatkan nutrisi lebih banyak (terutama energi dan protein). Nutrisi ini selain untuk memenuhi kebutuhan hidup pokok, diperlukan juga suplementasi nutrisi untuk pertumbuhan foetus, perkembangan organ mammae untuk produksi susu, organ reproduksi serta cadangan energi tubuh yang diperlukan pada fase laktasi. Respon dari kecukupan suplementasi ini diekpresikan melalui bobot lahir anak dan tingginya bobot sapih anak (Nnadi et al. 2007). Energi intake merupakan faktor nutrisi utama yang menentukan produksi susu pada fase laktasi. Pada minggu awal setelah kelahiran pertumbuhan anak tergantung dari konsumsi susu yang didapat dari induknya (Galvani et al. 2014). Karena susu merupakan satu-satunya nutrien dari anak yang baru lahir sehingga produksi susu induk menentukan daya hidup dan potensi produksi anak (Linden et al. 2009). Oleh karena itu meningkatkan nutrisi induk mungkin dapat secara efecktif meningkatkan performa anak (Galvani et al. 2014). Kebutuhan nutrisi induk domba tertinggi pada saat akhir kebuntingan dan awal masa laktasi, namun hal sebaliknya terjadi dengan kemampuan konsumsi pakan turun saat tersebut yang menyebabkan terbatasnya ketersediaan nutrisinya (Joy et al. 2014). Untuk mencukupi kebutuhan nutrisi biasanya induk domba diberikan pakan konsentrat atau dengan memobilisasi cadangan jaringan tubuh induk domba apabila terjadi keseimbangan energi negatif (Bacquier et al. 1987; McGovern et al. 2015).

Kenyon et al. (2009) perbaikan pakan saat kebuntingan tua terlihat pengaruhnya terutama pada induk yang mempunyai anak kembar stress karena kekurangan nutrisi lebih berat dialami oleh induk yang beranak kembar yang mengakibatkan rendahnya bobot lahir anak. Produksi susu dan kebutuhan nutrisi induk yang mempunyai anak kembar puncaknya pada minggu ke 3 sampai ke 4 setelah beranak, dilain pihak kemampuan konsumsi pakan belum mampu mencapai puncaknya sampai minggu ke 6 . Pedenera et al. (2017) melaporkan suplementasi pakan konsentrat pada domba induk bunting tua yang dipelihara ekstensif mampu meningkatkan kekuatan anak pada sesaat setelah dilahirkan sehingga memampukan anak berdiri dan mencari susu induknya untuk mendapatkan kolostrum sehingga menghindarkan anak dari kelaparan dan dapat menurunkan angka kematian anak neonatal. Suplementasi pakan konsentrat kaya energi seperti jagung dapat meningkatkan produksi kolostrum, membantu mencukupi kebutuhan energi dan meningkatkan daya imunitas anak baru lahir serta meningkatkan daya hidup anak domba (Banchero et al. 2015).

Domba komposit Garut yang dibentuk di Balitnak, Ciawi, Bogor mempunyai sifat prolifikasi anak 2, pertumbuhan perdagingan yang cepat. Namun demikian sifat tersebut harus didukung oleh pakan yang mampu mencukupi kebutuhannya sehingga dicapai produktivitas sesuai potensi genetiknya. Belum ada laporan kebutuhan nutrisi induk domba komposit Garut saat bunting tua maupun laktasi, oleh karena itu tujuan dari penelitian ini mengetahui kebutuhan nutrisi terutama energi induk domba komposit Garut fase bunting tua dan laktasi.

\section{MATERI DAN METODE}

\section{Ternak dan perlakuan pakan}

Penelitian dilakukan di stasiun percobaan Balai Penelitian Ternak lokasi Bogor. Ternak domba yang digunakan adalah Domba Induk Komposit Garut yang berjumlah 33 ekor induk bunting tua (umur kebuntingan 3 bulan) yang ditempatkan dalam 9 kandang 
kelompok berdasarkan bobot badan dan tiap kandangnya terdapat 3 sampai 4 ekor induk. Domba dikelompokkan berdasarkan bobot badan, masing-masing kelompok mendapatkan salah satu dari 3 perlakuan pakan konsentrat.

Domba diberikan pakan dasar rumput gajah (Penisetum purpureum) segar yang dicacah dan diberikan secara ad-libitum dan disuplementasikan dengan konsentrat sebanyak $2 \%$ dari berat badan. Konsentrat disusun dengan mengandung protein kasar 20\% dengan 3 level kandungan energi yaitu, 68\% (A), 73\% (B), dan 78\% (C) atau setara dengan energi metabolis 2,2 Mkal/kg (A); 2,3 Mkal/kg (B); dan 2,5 Mkal/kg (C). Energi metabolis pakan dihitung menggunakan persamaan dari MAFF (1982) $\mathrm{ME}=0,81$ (GExKCBO) dimana $\mathrm{GE}=$ energy kasar dan $\mathrm{KCBO}=$ kecernaan bahan organik pakan. Pakan percobaan diberikan selama 15 minggu, 3 minggu masa bunting tua dan 12 minggu selama laktasi. Komposisi pakan konsentrat perlakuan tercantum pada Tabel 1.

Tabel 1. Komposisi pakan konsentrat dan hitungan kandungan protein kasar dan energi

\begin{tabular}{lcccc}
\hline \hline \multirow{2}{*}{ Bahan pakan (\%) } & \multicolumn{3}{c}{ Perlakuan } & Rumput \\
\cline { 2 - 4 } Bungkil kelapa & R1 & R2 & R3 & \\
Dedak padi & 11 & 23 & 26 & \\
Jagung & 62 & 41 & 28 & \\
Bungkil kedelai & 10 & 16 & 27 & \\
Molasses & 8 & 8 & 10 & \\
Urea & 7 & 9 & 7 & \\
Garam & 2 & 2 & 1 & \\
Kapur & 1 & 1 & 1 & \\
Premix & 1 & 1 & & \\
Komposisi nutrisi & 1 & 1 & 20 & \\
Protein kasar (\% BK) & 20 & 20 & 78 & \\
Energi (TDN \%) & 68 & 73 & 2535 & \\
Energi metabolis (kkal/kg) & 2212 & 2375 & 1 & \\
\hline
\end{tabular}

Parameter yang diamati dilakukan selama fase laktasi adalah konsumsi pakan, bobot induk saat beranak, saat menyapih anak, jumlah anak sekelahiran, bobot lahir anak, bobot sapih anak, mortalitas anak prasapih, pertambahan bobot badan harian induk dan anak prasapih. Konsumsi pakan diukur dengan menimbang pakan pemberian dan pakan sisa. Penimbangan induk selama laktasi dan anak selama prasapih dilakukan setiap minggu untuk mengetahui perubahan bobot badannya.

\section{Rancangan percobaan dan analisa data}

Penelitian dilakukan menggunakan rancangan acak kelompok. Data yang diperoleh dianalisis dengan deskriptif untuk peubah konsumsi pakan, jumlah induk yang beranak, jumlah anak yang lahir, dan mortalitas anak prasapih. Data penampilan bobot badan anak dan induk beserta pertambahan bobot badannya dianalisa menggunakan sidik ragam (ANOVA). Apabila terdapat pengaruh nyata dari perlakuan pakan maka dilanjutkan 
dengan uji jarak ganda Duncan. Program yang digunakan untuk menganalisis data adalah Statistical Analysis Software (SAS) 6.2.

\section{HASIL DAN PEMBAHASAN}

\section{Konsumsi pakan}

Hasil analisis kimia pakan konsentrat dan rumput kandungan energi dan protein dari ransum yang digunakan lebih rendah dari formulasi yang disusun seperti pada Tabel 1 . Penyusunan formula ransum pada penelitian berdasarkan hasil analisis bahan pada tahun sebelumnya ataupun berdasarkan Tabel komposisi pakan di Indonesia. Namun setelah bahan pakan yang dibeli untuk memformulasi ransum dan dianalisa setelah penelitian selesai ternyata hasil analisa pada nilai nutrisinya tidak sama dengan patokan table bahan pakan ataupun dengan hasil analisa sebelumnya, bahkan lebih rendah sehingga kualitas pakan konsentrat yang diformulasi lebih rendah dari target nutrisi pakan yang sudah ditentukan. Untuk kandungan protein diantara ketiga ransum konsentrat mempunyai kandungan protein $16 \%$ lebih rendah dari yang diharapkan yaitu $20 \%$. Sedangkan pada kandungan energinya yang diharapkan level energinya meningkat ternyata pada perlakuan R2 lebih rendah dari R1. Kandungan energi masing-masing perlakukan adalah 1996,3; 1882,1; 2324 kkal/kg masing-masing untuk R1, R2 dan R3. Lebih rendahnya kandungan protein dan protein dari paakan yang dianalisa kemungkinan karena berfluktuasinya kualitas bahan pakan yang digunakan selama penelitian.

Rataan konsumsi bahan kering berdasarkan perlakuan dan bangsa ternaknya dapat dilihat pada Tabel 2. Rataan konsumsi bahan kering total masing-masing perlakuan antara 1515,2-1749,6 g/ekor/hari atau sebesar $107,98-117,12 \mathrm{~g} / \mathrm{kgBB}^{0,75}$. Dengan proporsi konsumsi rumput sebesar 37,4 - 40,0\%. Pada penelitian Mathius et al. (2003), konsumsi bahan kering untuk domba induk laktasi mempunyai rataan 1139,1-1145,6 g/ekor/hari atau sebesar $66,77-70,3 \mathrm{~g} / \mathrm{kgBB}^{0,75}$. Konsumsi bahan kering penelitian ini lebih tinggi daripada penelitian Mathius et al. (2003). Hal ini dapat dikarenakan bangsa domba yang digunakan pada penelitian ini, yaitu domba komposit Garut yang mempunyai sifat mengkonsumsi bahan kering lebih tinggi dibanding domba lokal yang digunakan pada penelitian Mathius et al. (2003). Yulistiani et al. (2015) melaporkan pada bahwa domba komposit Garut fase pertumbuhan memiliki konsumsi bahan kering paling tinggi dibandingkan dengan domba lokal yaitu $80,4 \mathrm{~g} / \mathrm{kgBB}^{0,75}$. Konsumsi bahan kering pada penelitian ini dalam range yang disarankan oleh Kearl (1982), yaitu berkisar antara 1350$1670 \mathrm{~g} / \mathrm{ekor} / \mathrm{hari}$.

Protein merupakan unsur penting dalam tubuh hewan dan diperlukan untuk memperbaiki sel dalam proses sintesis (NRC 2007). Pada Tabel 2, rataan konsumsi protein domba induk komposit Garut pada masing-masing perlakuan adalah 168,2 - 189,2 g/ekor/hari. Konsumsi protein pada penelitian lebih besar daripada kebutuhan protein domba menurut Kearl (1982). Kearl (1982) menyarankan bahwa kebutuhan protein domba induk fase laktasi dengan bobot badan antara 30-40 kg berkisar 143-176 g. Hal ini menujukkan bahwa kebutuhan protein untuk hidup pokok domba komposit Garut fase laktasi lebih tinggi dari standar yang disarankan Kearl (1982).

Rataan konsumsi energi metabolis total pada masing-masing perlakuan R1, R2 dan R3 secara berturut-turut adalah 2308,6-2893,6 kkal. Menurut Kearl (1982), energi metabolis yang diperlukan seekor domba induk fase laktasi dengan bobot badan $30-40 \mathrm{~kg}$ adalah 2990-3370 kkal. Hasil penelitian ini mengindikasikan konsumsi energi metabolis domba induk Komposit Garut pada penelitian ini masih dibawah dari yang disarankan 
Kearl (1982). Dengan pemberian konsentrat yang sudah dipatok $2 \%$ dari BB, namun ternyata meskipun masih terjadi kekurangan asupan energi domba-domba tersebut tidak mampu untuk mengkonsumsi rumput lebih banyak lagi dimana proporsi konsumsi rumput berkisar antara 37-40\% dari total konsumsi. Joy et al. (2014) melaporkan konsumsi pakan turun dari saat beranak sampai pada minggu 3, setelah itu konsumsi naik. Sebaliknya peningkatan konsumsi energi pada perlakuan R3 pada pakan konsentrat tidak mengurangi konsumsi rumput. Penelitian sebelumnya juga melaporkan suplementasi konsentrat tidak mengurangi konsumsi rumput sebagai pakan dasar (Kenyon et al. 2010, Kerslake et al. 2010, Joy et al. 2014; Pedernera et al. 2017).

Tabel 2. Konsumsi pakan komposit Garut induk fase laktasi

\begin{tabular}{lrrr}
\hline \hline \multirow{2}{*}{ Variabel } & \multicolumn{3}{c}{ Perlakuan } \\
\cline { 2 - 4 } & \multicolumn{1}{c}{$\mathrm{R} 1$} & \multicolumn{1}{c}{$\mathrm{R} 2$} & \multicolumn{1}{c}{$\mathrm{R} 3$} \\
\hline Konsumsi bahan kering (g/ekor/hari) & & & \\
$\quad$ Rumput & 566,73 & 610,62 & 716,74 \\
Konsentrat & 948,50 & 925,99 & 1032,89 \\
Total & 1515,24 & 1536,61 & 1749,63 \\
Konsumsi BK g/kg BB & 46,01 & 51,86 & 48,12 \\
Konsumsi protein (g/ekor/hari & & & \\
Rumput & 33,21 & 34,55 & 40,27 \\
Konsentrat & 135,01 & 141,11 & 148,97 \\
Total & 168,22 & 175,66 & 189,24 \\
Konsumsi PK g/kg BB & 5,14 & 5,11 & 5,20 \\
Konsumsi energi metabolis (kkal/ekor/hari) & & & \\
Rumput & 941,376 & 971,5735 & 1130,14 \\
Konsentrat & 1608,254 & 1455,537 & 2109,04 \\
Total & 2418,829 & 2308,593 & 2893,67 \\
Konsumsi energi metabolis kkal/kg BB & 81,42 & 77,21 & 89,66 \\
\hline
\end{tabular}

\section{Penampilan anak domba prasapih}

Penampilan anak prasapih yang diamati pada penelitian ini adalah bobot lahir, bobot sapih, dan pertambahan bobot badan harian $(\mathrm{PBBH})$ prasapih anak. Berdasarkan hasil sidik ragam perlakuan pakan dengan jumlah kandungan energi yang berbeda tidak berpengaruh nyata $(\mathrm{P}>0,05)$ terhadap bobot lahir anak, bobot sapih anak dan pertambahan bobot badan harian $(\mathrm{PBBH})$ prasapih domba komposit Garut. 
Tabel 3. Bobot lahir, bobot sapih (12 minggu) dan pertambahan bobot badan harian anak prasapih

\begin{tabular}{lccc}
\hline \multirow{2}{*}{ Variabel } & \multicolumn{3}{c}{ Perlakuan } \\
\cline { 2 - 4 } & $\mathrm{R} 1$ & $\mathrm{R} 2$ & $\mathrm{R} 3$ \\
\hline Bobot lahir anak/ekor (kg) & 3,10 & 3,1 & 3,125 \\
Anak tunggal & 1,89 & 1,85 & 2,525 \\
Anak kembar & 2,29 & 2,28 & 2,82 \\
Rataan bobot lahir/ekor & 3,40 & 3,51 & 3,76 \\
Bobot lahir anak per-induk & & & \\
Bobot sapih anak/ekor (kg) & 15,0 & 15,36 & 15,25 \\
Anak tunggal & 7,98 & 7,55 & 9,87 \\
Anak kembar & 11,49 & 11,89 & 12,56 \\
Rataan bobot sapih/ekor (kg) & 15,52 & 14,5 & 16,75 \\
Bobot sapih anak per-induk (kg) & & \\
Pertambahan bobot badan harian anak (PBBH) & $(\mathrm{g} / \mathrm{ekor} / \mathrm{hari})$ & & \\
Anak tunggal & 114,4 & 123,78 & 126,3 \\
Anak kembar & 59,4 & 61,54 & 73,72 \\
Rataan PBBH praspih & 86,9 & 96,12 & 99,95 \\
PBBH prasapih anak per-induk (g/hr) & 112,4 & 118,2 & 133,3 \\
\hline
\end{tabular}

Tabel 3 menampilkan bobot lahir anak, bobot sapih anak dan PBBH anak prasapih. Perbedaan kandungan energi pakan konsentrat tidak berpengaruh terhadap bobot lahir anak. Menurut Gardner et al. (2007) konsumsi energi pada akhir kebuntingan merupakan faktor dominan yang menentukan bobot lahir anak. Pada penelitian ini pakan untuk induk domba Komposit Garut pada fase bunting tua pakannya sama, perlakuan diberikan setelah induk beranak, mungkin itu yang menyebabkan bobot lahir anak tidak dipengaruhi oleh perlakuan tingkat energi yang berbeda. Bobot lahir anak perekor untuk anak tunggal lebih berat dibanding anak kembar, hal sama juga dilaporkan oleh Perdenera et al. (2017). Bobot lahir anak perekor maupun bobot lahir perinduk pada penelitian ini tidak jauh berbeda dengan penelitian Mathius et al. (2003), yaitu berkisar antara 2,302,71 kg dan 3,44-4,0 kg masing-masing untuk bobot lahir perekor dan bobot lahir anak per induk pada domba Garut.

Rataan dari seluruh pengamatan menunjukkan bahwa rataan bobot sapih anak 11,59 $\mathrm{kg}$. Tidak pengaruh perlakuan pakan terhadap bobot sapih maupun pertambahan bobot badan (PBBH) anak prasapih. Hal yang sama juga dilaporkan oleh Terreao et al. (2014) pada berbagai domba crossing yang diberi suplementasi pakan konsentrat. Hasil penelitian ini tidak jauh berbeda dengan penelitian Nafiu (2003). Nafiu (2003) melaporkan bobot sapih domba komposit Garut pada kondisi pakan yang jelek rataan bobot sapih sebesar 10,87 kg/ekor dan meningkat menjadi 12,57 kg/ekor pada kondisi pakan yang baik. Thompson et al. (2011) pertumbuhan anak prasapih sampai sapih dipengaruhi sebagian besar oleh konsumsi susu induk. Meningkatnya energi pakan yang dikonsumsi induk selama laktasi meningkatkan produksi susu dan meningkatkan pertumbuhan anak. Namun pada penelitian ini peningkatan energi dalam pakan 
konsentrat masih belum mampu meningkatkan bobot sapih anak, mungkin karena energi pakan yang diberikan masih belum mencukupi kebutuhan induk laktasi (Tabel 2).

Rataan PBBH prasapih anak masing-masing perlakuan adalah 94,32 g/ekor Hasil penelitian ini masih lebih rendah dengan penelitian Istiqomah (2006). Istiqomah (2006) melaporkan rataan PBBH prasapih domba Garut jantan sebesar 107,40 g/ekor dan pada domba Garut betina sebesar 99,12 g/ekor. Demikian pula yang dilaporkan oleh Matius et al (2003) rataan pertambahan bobot badan harian $(\mathrm{PBBH})$ domba lokal prasapih dengan berbagai tingkat kandungan energi dan protein adalah 111,9-160 g/hari. Lebih rendahnya PBBH prasapih pada anak domba penelitian yang dilaporkan disini mungkin disebabkan oleh rendahnya konsumsi energi yang lebih rendah dari yang disarankan oleh Kearl (1982). Seperti yang dilaporkan oleh DeCastro et al. (2012) bahwa energi pakan yang rendah (2,2 atau 2,0 Mcal/kg ME) menghasilkan produksi susu yang lebih rendah dibanding energi pakan 2,4 Mcal/kg ME, yang pada gilirannya menghasilkan bobot sapih yang rendah. Selanjutnya McGovern et al. (2015) mengidentifikasi adanya korelasi antara produksi susu induk pada 28 dan 56 hari setelah beranak dengan pertumbuhan masingmasing pada anak tunggal dan anak kembar. Pada umur tersebut anak bergantung pada susu sebagai satu-satunya sumber nutrisinya. Sehingga pada umur tersebut produksi susu induk merupakan faktor utama yang menentukan tingkat pertumbuhan anak pada masa awal hidupnya. PBBH anak domba Komposit Garut pada penelitian ini sebanding dengan yang dilaporkan oleh Inounu et al. (2003) pada domba Garut dan persilangannya dengan domba St Croix maupun dengan domba Moulton Charolais.

\section{Penampilan induk selama laktasi}

Penampilan bobot badan induk yang diamati dalam penelitian ini adalah bobot badan induk sesaat setelah beranak, bobot badan induk saat menyapih dan pertambahan bobot badan harian induk selama laktasi. Hasil analisis statistik menunjukkan bahwa tidak ada pengaruh nyata $(\mathrm{P}>0,05)$ perlakuan pakan terhadap bobot induk sesaat setelah beranak, bobot badan induk saat menyapih dan perubahan bobot badan induk selama laktasi. Adapun bobot badan induk sesaat setelah beranak, saat menyapih anak, dan PBBH induk selama laktasi dapat dilihat pada Tabel 4.

Rataan bobot induk dari semua perlakuan sesaat setelah beranak adalah $37,12 \mathrm{~kg}$. Bobot induk sesaat setelah beranak pada penelitian ini lebih tinggi daripada penelitian Inounu et al. (2006). Inounu et al. (2006) melaporkan bahwa bangsa domba yang berdarah $25 \%$ St. Croix, 25\% Moulton Charolais dan 50\% Garut mempunyai bobot induk sesaat setelah beranak sebesar 35,5 kg/ekor. Sedangkan rataan semua perlakuan bobot induk saat menyapih adalah $35,09 \mathrm{~kg}$, dengan demikian terjadi rataan penurunan bobot badan induk selama laktasi sebesar $2,03 \mathrm{~kg}$ dengan kata lain rataan PBBH induk fase laktasi sebesar -22,76 gr/ekor/hr. DeCastro et al. (2012) melapokan kehilangan bobot badan selama laktasi untuk induk beranak kembar lebih besar dibanding induk beranak tunggal. Pada penelitian kehilangan bobot badan induk selama laktasi tidak berbeda nyata antara anak kembar dan anak tunggal. Menurut DeCastro et al. (2012) kehilangan bobot badan yang besar pada anak kembar karena kebutuhan nutrisi yang lebih banyak selama induk memelihara anak kembar, dengan diindikasikannya bobot lahir maupun bobot sapih anak per induk lebih besar pada anak kembar. Sedangkan pada penelitian ini bobot sapih maupun bobot lahir anak per induk tidak berbeda nyata antara anak kembar dengan anak tunggal, mungkin hal ini yang menyebabkan tidak berbeda nyata pada penelitian ini kehilangan bobot badan induk untuk anak tunggal maupun anak kembar. 
Tabel 4. Bobot badan induk sesaat setelah beranak, saat menyapih anak dan pertambahan bobot badan induk selama laktasi

\begin{tabular}{|c|c|c|c|}
\hline \multirow{2}{*}{ Variabel } & \multicolumn{3}{|c|}{ Perlakuan } \\
\hline & R1 & $\mathrm{R} 2$ & $\mathrm{R} 3$ \\
\hline \multicolumn{4}{|l|}{ Bobot induk saat beranak $(\mathrm{kg})$} \\
\hline Anak tunggal & 33,58 & 37,7 & 37,8 \\
\hline Anak kembar & 38,8 & 38,75 & 38,8 \\
\hline Rataan bobot induk saat beranak & 35,33 & 37,93 & 38,1 \\
\hline \multicolumn{4}{|l|}{ Bobot induk saat menyapih anak $(\mathrm{kg})$} \\
\hline Anak tunggal & 33,0 & 34,41 & 34,5 \\
\hline Anak kembar & 38,6 & 35,8 & 37,9 \\
\hline Rataan bobot induk saat menyapih & 34,9 & 34,73 & 35,67 \\
\hline \multicolumn{4}{|c|}{ Pertambahan bobot badan harian induk selama laktasi (g/ekor/hari) } \\
\hline Anak tunggal & $-6,2$ & $-36,5$ & $-36,11$ \\
\hline Anak kembar & $-2,67$ & $-32,4$ & $-10,4$ \\
\hline Rataan PBBH induk laktasi & $-5,13$ & $-35,61$ & $-27,54$ \\
\hline
\end{tabular}

Tabel 5. Jumlah induk beranak, jumlah anak yang lahir dan jumlah kematian anak prasapih

\begin{tabular}{|c|c|c|c|c|c|}
\hline \multirow{2}{*}{ Variabel } & \multicolumn{4}{|c|}{ Perlakuan } & \multirow{2}{*}{ Tota } \\
\hline & $\mathrm{R} 1$ & & $\mathrm{R} 2$ & R3 & \\
\hline \multicolumn{6}{|c|}{ Jumlah induk beranak (ekor) } \\
\hline Tunggal & 5 & 6 & & 4 & 26 \\
\hline Kembar & 5 & 4 & & 2 & \\
\hline \multicolumn{6}{|c|}{ Jumlah anak lahir (ekor) } \\
\hline Tunggal & 5 & 6 & & 4 & 38 \\
\hline Kembar & 10 & 9 & & 4 & \\
\hline \multicolumn{6}{|c|}{ Kematian anak prasapih (ekor) } \\
\hline Tunggal & - & - & & - & 6 \\
\hline Kembar & 3 & 3 & & - & \\
\hline
\end{tabular}

Rataan kehilangan bobot badan induk fase laktasi pada penelitian ini lebih rendah dibanding hasil yang dilaporkan oleh Mathius et al. (2003) yang melaporkan rataan PBBH induk fase laktasi sebesar $-2,35 \mathrm{~kg}$. Penurunan bobot badan induk selama laktasi ini terjadi karena lemak tubuh yang ada digunakan sebagai sumber energi. Selama laktasi kebutuhan nutrisi meningkat namun tidak dapat dikompensasi dengan peningkatan konsumsi pakan terutama pada masa awal laktasi sehingga untuk memenuhi kebutuhan nutrisi induk memobilisasi jaringan tubuhnya (Bell 1995; Duehlmeier et al. 2011; Perdenera et al. 2017). Dalam kondisi ini produksi susu dan pertumbuhan anak akan lebih tinggi pada induk yang mempunyai cadangan lemak lebih banyak (BCS >2,5). Induk dengan kondisi pada saat beranak karena nutrisi yang baik selama kebuntingan akan mempunyai banyak cadangan lemak untuk dimobilisasi selama fase laktasi. Bobot badan 
anak saat disapih menggambarkan pengaruh kumulatif dari kecukupan nutrisi induk saat kebuntingan dan laktasi (Thomson et al. 2011).

Jumlah induk yang beranak pada penelitian ini keseluruhannya adalah 26 ekor dari 33 ekor induk yang diberikan perlakuan pakan. Terdapat 1, 2 dan 6 ekor induk domba masing-masing dari perlakuan R1, R2 dan R3. Pada penelitian ini setelah perkawinan yang dilakukan secara kelompok dimana jantan dimasukkan ke kandang betina selama 2 kali estrus, tidak dilakukan pemeriksaan kebuntingan terhadap induk-induk yang sudah dikawinkan sehingga terjadi ketidak ratanya jumlah induk yang beranak. Jumlah anak sekelahiran pada penelitian ini adalah 1,46. Dari 38 anak yang dilahirkan terdapat 6 ekor anak yang mati. Kematian anak pada perlakuan A, 2 ekor terjadi pada saat kelahiran bersamaan dengan induknya yang mati saat beranak dan 1 ekor saat kelahiran. Sedangkan pada perlakuan B terdapat kematian 2 ekor saat lahir dan 1 ekor mati setelah umur 4 minggu yang berasal dari anak kembar 3 . Anak yang mati saat lahir mempunyai bobot lahir dibawah $2 \mathrm{~kg}$ (1,1-1,5). Kematian anak neonatal (dari lahir sampai 72 jam setelah dilahirkan) berkaitan dengan rendahnya bobot lahir anak (DeCastro et al, 2012). Pada penelitian yang dilaporkan oleh Perdenera et al. (2017) anak domba dengan bobot lahir yang rendah berkaitan dengan ketahanan daya hidup anak neonatal, pada bobot lahir yang rendah anak menjadi lemah, perlu waktu yang lama untuk berdiri dan mulai menyusu ke induknya. Padahal pada umur 0-28 hari anak domba sangat bergantung pada susu dari induknya sebagai sumber utama susunya (Torreao et al. 2014). Pada anak yang mempunyai bobot lahir yang lebih tinggi, pada saat dilahirkan dapat langsung berdiri dan mencari susu induknya. Pada perlakuan R3 tidak terdapat kematian anak prasapih karena kebanyakan anaknya lahir tunggal. Anak tunggal mempunyai bobot lahir yang lebih besar dibanding anak kembar (Tabel 3) sehingga mempunyai daya hidup yang lebih besar dibanding anak kembar.

\section{KESIMPULAN}

Level energi yang berbeda dalam pakan konsentrat menghasilkan respon yang sama terhadap produktivitas induk domba komposit Garut fase laktasi. Suplementasi konsentrat dengan kandungan protein kasar 16\% dan EM 1,9 Mcal/kg yang diberikan 2\% dari BB, dengan pemberian rumput sebagai pakan dasar secara adlibitum. Disarankan perbaikan pemberian pakan perlu dilakukan mulai dari akhir kebuntingan untuk meningkatkan produkstivitas induk domba Komposit Garut.

\section{UCAPAN TERIMA KASIH}

Ucapan terima kasih disampaikan kepada Sdr. Daniswara Gandana Putra, Nurjaya, Maplani yang telah membantu dalam pelaksanaan penelitian dan pengumpulan data.

\section{DAFTAR PUSTAKA}

Bocquier F, Thériez M, Brelurut A. 1987. The voluntary hay intake by ewes during the first weeks of lactation. Anim Prod. 44:387-394.

Banchero GE, Milton JTB, Lindsay DR, Martin GB, Quintans G. 2015. Colostrum production in ewes: a review of regulation mechanisms and of energy supply. Animal.9:831-837.

Bell AW. 1995. Regulation of organic nutrient metabolism during transition from late pregnancy to early lactation. J Anim Sci. 73:2804-2819. 
Bradford GE. 1993. Small ruminant breeding strategies for Indonesia. In: Subandriyo, Gatenby, editors. Advances in small ruminant research in Indonesia. Bogor (Indonesia): SR-CRSP Central Research Institue for Animal Science. p. 83-94.

DeCastro FAB, Ribeiro EL, de Azambuja, Mizubuti IY, Da Silva LDF, Barbosa MAA, De Sousa CL, Pereira de Paiva FH, Koritiaki NA. 2012. Influence of pre and postnatal energy restriction on the productive performance of ewes and lambs. R Bras Zootec. doi: dx.doi.org/10.1590/S1516-35982012000400017.

Duehlmeier R, Fluegge I, Schwert B, Parvizi N, Ganter M. 2011. Metabolic adaptations to pregnancy and lactation in German Blackheaded Mutton and Finn sheep ewes with different susceptibilities to pregnancy toxaemia. Small Rumin Res. 96:178-184.

Galvani DB, Pires CC, Hübner CH, Carvalho S, Womme TP. 2014. Growth performance and carcass traits of early-weanedlambs as affected by the nutritional regimen of lactating ewes. Small Rumin Res. 120:1-5.

Gardner DS, Buttery PJ, Daniel Z, Symonds ME. 2007. Factors affecting birthweight in sheep: Maternal environment. Reproduction. 133:297-307.

Joy R. Ripoll-Bosch, Sanz A, Molino F, Blasco I, Álvarez-Rodríguez J. 2014. Effects of concentrate supplementation on forage intake,metabolic profile and milk fatty acid composition ofunselected ewes raising lambs. Anim Feed Sci Technol. 187:19-29.

Kearl LC. 1982. Nutrient requirements of ruminants in developing countries. Utah (USA): International Feedstuff Institute, Utah Agricultural Experiement Station, Utah State University.

Kenyon PR, Blair HT, Jenkinson CMC, Morris ST, Mackenzie DDS, Peterson SW, Firth EC, Johnston PL. 2009. The effect of ewe size and nutritional regimen beginning in early pregnancy on ewe and lamb performance to weaning. New Zealand J Agric Res. 52:203212.

Ministry of Agriculture, Fisheries, and Food. 1984. Energy allowances and feeding system for ruminants. HMSO, London (UK): Ministry of Agriculture, Fisheries and Food.

Mathius IW, Sastradipradja D, Sutardi T, Natasasmita A, Sofyan LA, Sihombing DTH. 2003 Studi strategi kebutuhan energi-protein untuk domba lokal: 5 induk fase laktasi. JITV. 8:26-39.

McGovern FM, Campion FP, Sweeney T, Fair S, Lott S, Boland TM. 2015. Altering ewe nutrition in late gestation: II. The impact on fetal development and offspring performance. J Anim Sci. 93:4873-4882. doi: 10.2527/jas2015-9020.

Nnadi PA, Kamalua TN, Onah DN. 2007. Effect of dietary protein supplementation on performance of West African Dwarf (WAD) does during pregnancy and lactation. Small Rumin Res. 71:200-204.

National Research Council. 2007. Nutrient requirements of small ruminants: Sheep, goats, cervids, and new world camelids. 1st ed. Washington DC (USA): National Academy Press.

Pedernera M, Pérez-Sánchez LA, Romero-Aguilar LD, Aguirre V, Flores-Pérez I, Vázquez R, Orihuela A. 2017. Effects of high concentrate supplementation of Saint Croix sheep during peripartum on neonatal lamb behavior. J Appl Anim Res. 46:720-724.

Robinson JJ. 1986. Formulation of feeding strategies for sheep. In: Livingstone RM, editor. Proceeding of the Evaluation Modern Aspects-Problems-Future Trends. Aberdeen (Skotlandia): The Rowett Research Institute, University of Aberdeen. hlm. 76-92. 
Russel AJF. 1979. The Nutrition of pregnant ewes. In: The British Council, editors. Management and diseases of sheep. London (UK): The British Council. p. 221-240.

Subandriyo, Setiadi B, Inounu I, Jarmani SN, Adiati U, Priyanto D, Asmarasari SA. Rokhman, Supardi K, Aminah S. 2009. Pemuliaan domba komposit dengan tingkat reproduksi $>90 \%$ dan bobot dewasa $30 \mathrm{~kg}$ : Analisis lanjutan pemantapan bibit domba komposit. Laporan Hasil Penelitian TA 2009. Bogor (Indonesia): Balai Penelitian Ternak.

Thompson AN, Ferguson MB, Campbell A.JD. Gordon DJ, Kearney GA, Oldham CM, Paganoni BL. 2011. Improving the nutrition of Merino ewes during pregnancy and lactation increases weaning weight and survival of progeny but does not affect their mature size. Anim Prod Sci. 51:784-793.

Torreão JN, da Costa, Rocha AM, Torreão CAM, Bezerra LR, Gottardi FP, De Araújo MJ, De Souza ELJ, Oliveira RL. 2014. Concentrate supplementation during pregnancy and lactation of ewes affects the growth rate of lambs from a variety of crosses. $\mathrm{R}$ Bras Zootec. 43:544-550.

Van der Linden DS, Kenyon PR, Blair HT, Lopez-Villalobos N, Jenkinson CM, Peterson SW, Mackenzie DDS. 2009 .Effects of ewe size and nutrition on fetal mammary gland development and lactational performance of offspring at their first lactation. J Anim Sci. 87:3944-3954. 